\title{
Mechanism of the Tracheal Smooth Muscle Relaxant Activity of the Cordia myxa Plant Extract in Sheep
}

\author{
Muhannad A. A. AlBayaty and Farid J.. AlTahan \\ Dept.of Physiology \& Pharmacology- Collage of Vet. Med.-Baghdad \\ University- Iraq
}

\begin{abstract}
Summary
Isolated tracheal smooth muscle of sheep, which is pharmacologically precontracted by acetylcholine, induces relaxation when exposed to Cordia myxa plant extract. The aim of the present study was to typify the mechanism of Cordia myxa extract induced by relaxation in the sheep trachea. 1. Cordia myxa extract relaxed both epithelium-intact and denuded sheep trachea rings contracted by acetylcholine. The scale of relaxation on Cordia myxa extract was dependent on the treated dose and slightly greatly in epithelium denuded rings than in epithelium-intact preparations. 2. L-NAME (10 nM-100 uM) but not DNAME completely inhibited the relaxation in a concentration dependent manner. 3. The Cordia myxa extract -induced relaxation was inhibited by methylene blue $(1-100 \mathrm{uM})$, and verapamil $(100 \mathrm{nM})$, and removal of extracellular $\mathrm{Ca}^{2+}$. In contrast, Cordia myxa extract - induced relaxation was potentiated by Nw-nitro-Larginine (L-NOARG) treatment. These results put forward that Cordia myxa extract -induced relaxation may be due to nitric oxide from exogenously administered L-arginine as well as endogenous nitric oxide donors such as amino acid and arginine derivatives. Additional suggestion is that Cordia myxa extract stimulates the expression of nitric oxide synthesis, and its activity for nitric oxide generation is dependent on cytosolic $\mathrm{Ca}^{2+}$ originated from extracellular space.
\end{abstract}




\title{
آلية النشاط الارخائي للعضلة الملساء في رغامي الاغنام لمستخلص نبات الكورديا ميكسا
}

\author{
مهند عبد الستار و فريد جميل الطحان \\ فرع الفسلجة و الادوية- كلية الطب البيطري-جامعة بغداد- العراق ولئ جميل
}

\section{الخلاصة}

استحداث الارخاء في العضله الملساء المعزولة لرغامي الاغنام بمستخلص نبات الكورديا ميكسا المسبوق بالتقلص المستحدث دوائيا بالاسيتايل كولين. مستهدفة هذه الدراسه تصنيف الية احداث الارخاء

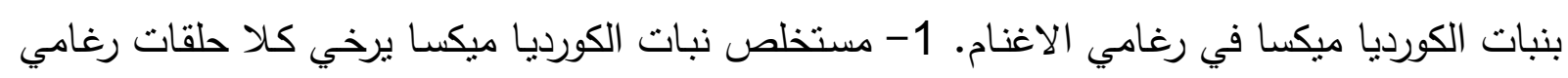

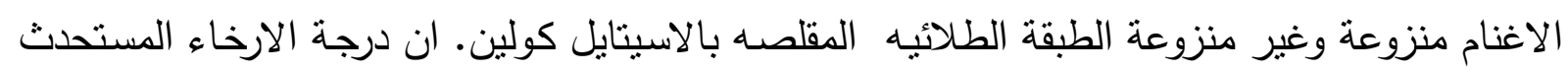

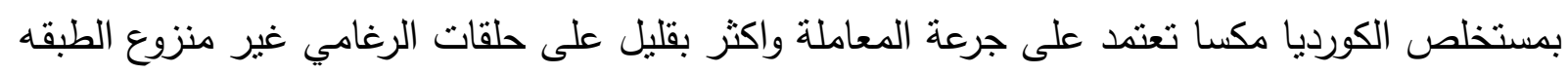

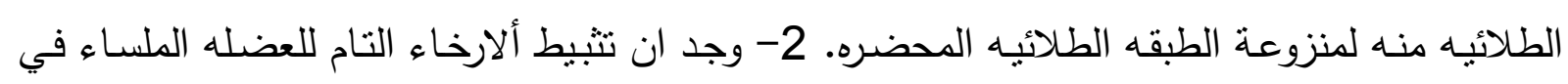

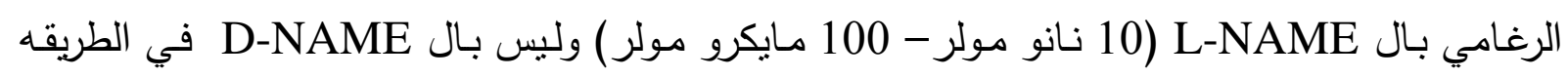
المعتمده على التركيز • 3- ألارخاء المحدث بمستخلص نبات الكورديا ميكسا ثبط بـ 1 -10مايكرو مولر بالر

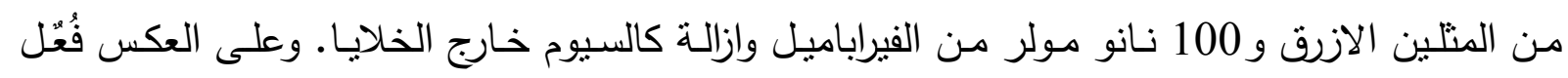
الارخاء المحدث بمستخلص الكورديا ميكسا بالمعامله ب Nw-nitro-Larginine (L-NOARG)

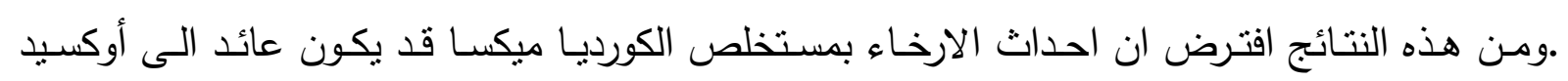

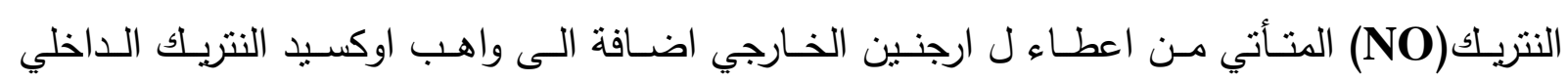

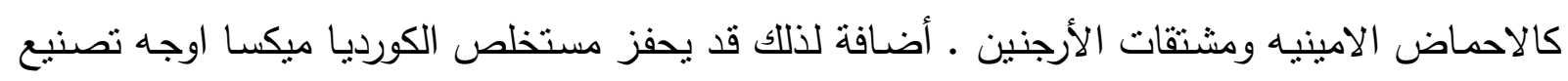
اوكسيد النتريك وفعالية نوليده المعتمد على كالسيوم السايتوبلازم المتأتي من خارج الخليه

\section{Introduction}

In the industrialized countries, asthma has become one of the most important chronic diseases in terms both of morbidity, days of work and school lost, and of the difficult of medical care. It is therefore highly appropriate to study all potential therapies, which may reduce suffering and improve the course of this very common and for many patients troublesome disease (1). 
Although asthma is not a well defined disease entity it is now usually accepted among clinical investigators that it is mainly characterized by inflammation in the airways and contracted of tracheal smooth muscle. Asthma therapy there for has to be target on the treatment of these inflammatory and narrowing of tracheal rings in order to control both symptoms and progression the disease (2).

Diet and medicinal plants play an important role in the prophylaxis and therapy of asthma. The fruit of Cordia myxa (Linn) natural order: Boraginaceae (Fam.), known as "bamber" in Iraq has been used for the prophylaxis treatment of asthma, which has been reported that fruit Cordia myxa has significant analgesic and anti-inflammatory and tracheal smooth muscle relaxant due to flavinoids contents. This study describes some of the pharmacological effect of Cordia myxa and an attempt has also been mad to investigate the mechanism of action (3).

In 1995, Barnes, demonstrated the role of epithelial cells during the relaxation of isolated rabbit trachea exposed to acetylcholine (4).This observation has become crucial to the understanding of the regulation of tracheal smooth muscle tone. His simple pharmacological experiment has initiated numerous studies on a wide variety of blood vessels and tracheal smooth muscle and has lead to the understanding of a new physiological role for nitric oxide. In addition, nitric oxide is implicated in the pathogenesis of tracheal hyperesponsiveness. There is now considerable evidence that nitric oxide plays a role in regulating tracheal function (5 and 2$)$.

Over decade ago, several investigators reported that the isolated tissues, which were pharmacologically relaxed when exposed to Cordia myxa extract (3). In these reports, changes in the ionic environment of the tissue found that $\mathrm{Na}^{+}$and $\mathrm{Ca}^{2+}$ were essential for relaxation, which proved reversible (6). Recently, relaxation of smooth muscle by Cordia myxa extract is hypothesized to result from nitric oxide (NO) released from plant-activable stores (7). In addition, a study reported enhanced relaxation of tracheal smooth muscle from rats administered the NO synthase (NOS) inhibitor Nw-nitro-Larginine (LNNA) (8). Presumably, this potentiated relaxation was due to NO created from the Cordia myxa induced decomposition of the $\mathrm{NO}_{2}$ moiety of LNNA. Nitrite is a stable end product of nitric oxide metabolism. In fasted individuals, as much as $90 \%$ of circulating nitrite is resultant from the L-arginine nitric oxide pathway and is a valid indicator of nitric oxide yield (9). Although nitric oxide appears to be the major bronchodilator released by epithelial cells in a vast majority of tracheal smooth muscle, other substances, some of them still unknown, may also play a role $(8)$.

Previously, several reports have been investigated the roles of nonadrenergic noncholinergic (NANC) nerve fibers which may act on NANC 
nerve transmitter substances. Among the substances of putative NANC neurotransmitters, purine nucleotides are considered as the most likely candidate for NANC neurotransmitter (10). However, whether NO is also one of the NANC a member has not been studied yet. Thus, in this study we examined the role of NOS isoforms and $\mathrm{Ca}^{2+}$ ion at the sheep tracheal smooth muscle.

\section{Materials and Methods}

\section{Materials}

The following chemicals were used: Phenylephrine $\mathrm{HCl}$ (PE), acetylcholine chloride (Ach), Nw-nitro-L-arginine methyl ester (L.NAME), Nwnitro-D-arginine methyl ester (D.NAME), methylene blue (MB), L.arginine (L.Arg) and verapamil. These chemicals were purchased from the Sigma Chemical Co. Other chemicals used were of analytical grade. Cordia myxa were extracted by soxehlate apparatus as hot alcoholic extraction method,

\section{Animals Animals}

The sheep used in this study, either sex, weighing 25-30 Kg, were slaughter by decapitation, and exsanguinated. Sheep were housed in Semi open door. Throughout this study, sheep were fed and watered ad libitum.

\section{Tissue preparation}

The tracheal smooth muscle from the exsanguinated sheep was removed. the trachea cut into rings (five cartirge ring) and the surrounding fat and connective tissue removed in $40 \mathrm{C}^{\circ}$ ice-cold Krebs ringer solution, of the following composition $(\mathrm{mM}): \mathrm{NaCl}, 120 ; \mathrm{KCl}, 4.75$; Glucose, 6.4; $\mathrm{NaHCO} 3,25$; $\mathrm{KH} 2 \mathrm{PO} 4,1.2 ; \mathrm{MgSO} 4,1.2$; and $\mathrm{CaCl} 2,1.7$ (mM, pH 7.4), and used for organ bath studies.

\section{Recording system}

The tracheal ring was suspended horizontally between two parallel platinum wire electrodes, the lower end was fixed at basement of a waterjacketed organ bath (volume $10 \mathrm{ml}$ ), and the upper end was attached to a transducer. The bath medium was maintained at $37 \pm 0.5 \mathrm{C}^{\circ}$ and gassed with irritator. Changes in the tracheal smooth muscle preparation tension were recorded by an isometric force transducer (type A) and ink-writing curvilinear polygraph (physiographic system, Texas) (11).

\section{Relaxation maneuvers}


At the beginning of the experiments, the preparations were allowed to equilibrate at a $3 \mathrm{~g}$ resting tension for $60 \mathrm{~min}$ prior to chemical administration. To allow studies of the relaxation, each ring was precontracted by $10^{-8} \mathrm{uM}$ acetylcholine (Ach). After a plateau was reached, the tracheal ring was exposed to Cordia myxa extract (alcoholic extract) for indicated concentration 10\%. This Cordia myxa extract application was treated at $0.3 \mathrm{ml}$. The tracheal rings was then rinsed with $\mathrm{Ca} 2+$ containing or free Krebs ringer solution and allowed to rest for $30 \mathrm{~min}$. After incubation, the same procedure was repeatedly applied on the same preparation (11).

\section{Results}

\section{Effects on epithelium of Cordia myxa extract - and theophylline -induced relaxation}

Theophylline-induced relaxation was completely diminished in epithelium-denuded tracheal smooth muscle (Figure 1, upper panel A). Cordia myxa extract induced dose-dependent relaxation in both epithelium-intact and denuded tracheal smooth muscle contracted with acetylcholine (Ach). Cordia myxa extract -induced relaxation was dependent of epithelium. Nevertheless, the potentiation of relaxation of was significantly $(\mathrm{P}<0.01)$ greater in epithelium denuded than epithelium intact tracheal ring (Lower panel $\mathbf{B}$ of Figure 1 and Figure 2).

\section{Effects of L-arginine and NOS inhibitor on Cordia myxa extract induced relaxation}

Sheep tracheal smooth muscle precontracted with $1 \mathrm{uM}$ Ach showed dose dependent relaxation of Cordia myxa extract treatment. Increased smooth muscle tone was significantly $(\mathrm{P}<0.01)$ diminished with nitric oxide synthase inhibitor, L-NAME (Figure 3A) but not with derivative, D-NAME (Figure 3B). The magnitude of the relaxation was slightly increased with D-NAME (Figure 3B). Moreover, the developed tone gradually depressed upon L-arginine administration and then showed that the augmented relaxation by L-arginine was also dependent on the treatment concentration to Cordia myxa extract (Figure $3 \mathrm{C})$.

\section{Inhibitory effect of methylene blue (MB) on Cordia myxa extract induced relaxation}

To identify the interrelation of cGMP and relaxants derived from Cordia myxa extract-induced relaxation, soluble guanylyl cyclase inhibitor, methylene blue was introduced in sheep trachea. Figure 4 show that methylene blue inhibits 
the potentiation of Cordia myxa extract -induced relaxation, in a concentration dependent manner.

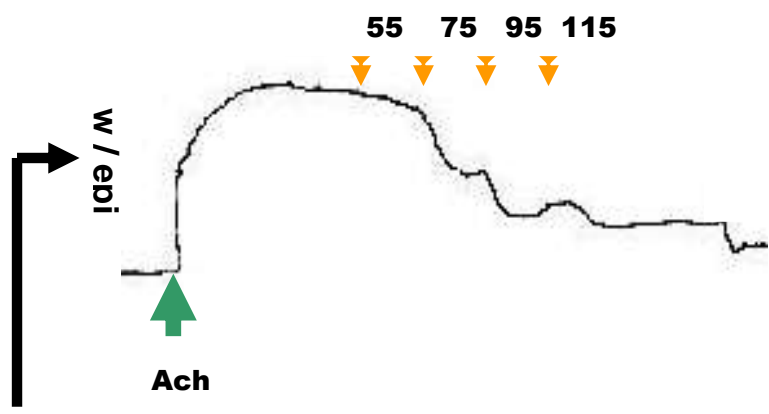

A

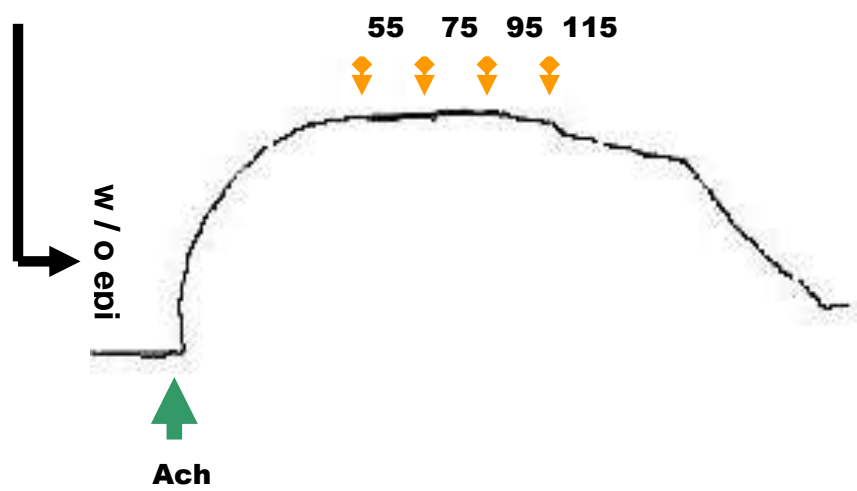

$\begin{array}{llll}0.3 & 0.5 & 0.7 & 0.9\end{array}$

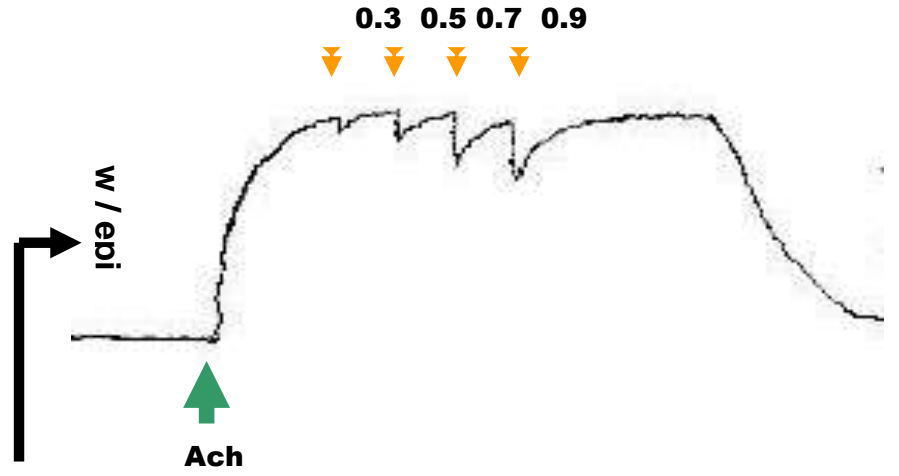

B

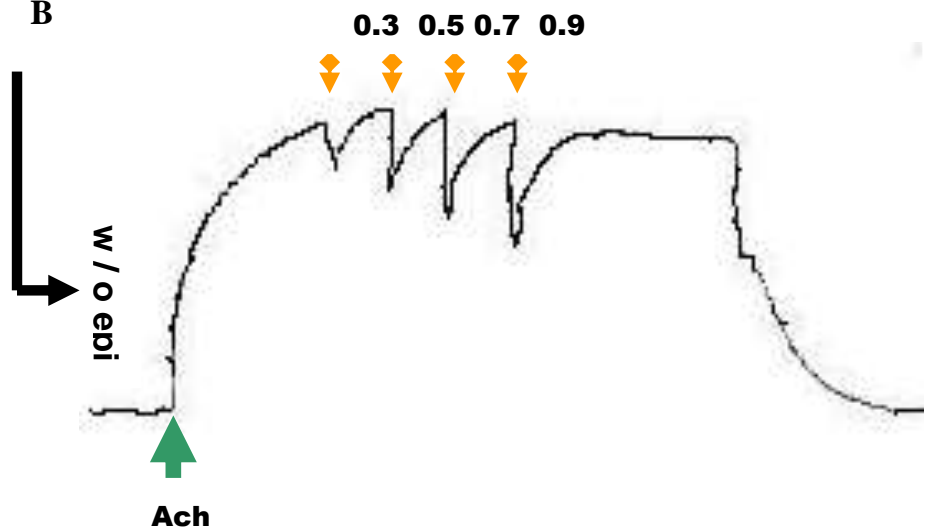

Figure 1:

Effects of Cordia myxa extract treatment on tracheal smooth muscle relaxation of sheep. Acetylcholine (Ach) induced precontraction in a sheep trachea, which had been incubated in normal Krebs solution with epithelium (w / epi) and denuded epithelium (w / o epi).

A. The tracing of theophylline (numbers indicate log micromolar concentration)-induced relaxation in w/epi and w/o epi preparations. since

B. The tracing of Cordia myxa extract induced relaxation in which the numbers indicate Cordia myxa extract treated concentration in w/ epi and w/o epi preparations. 


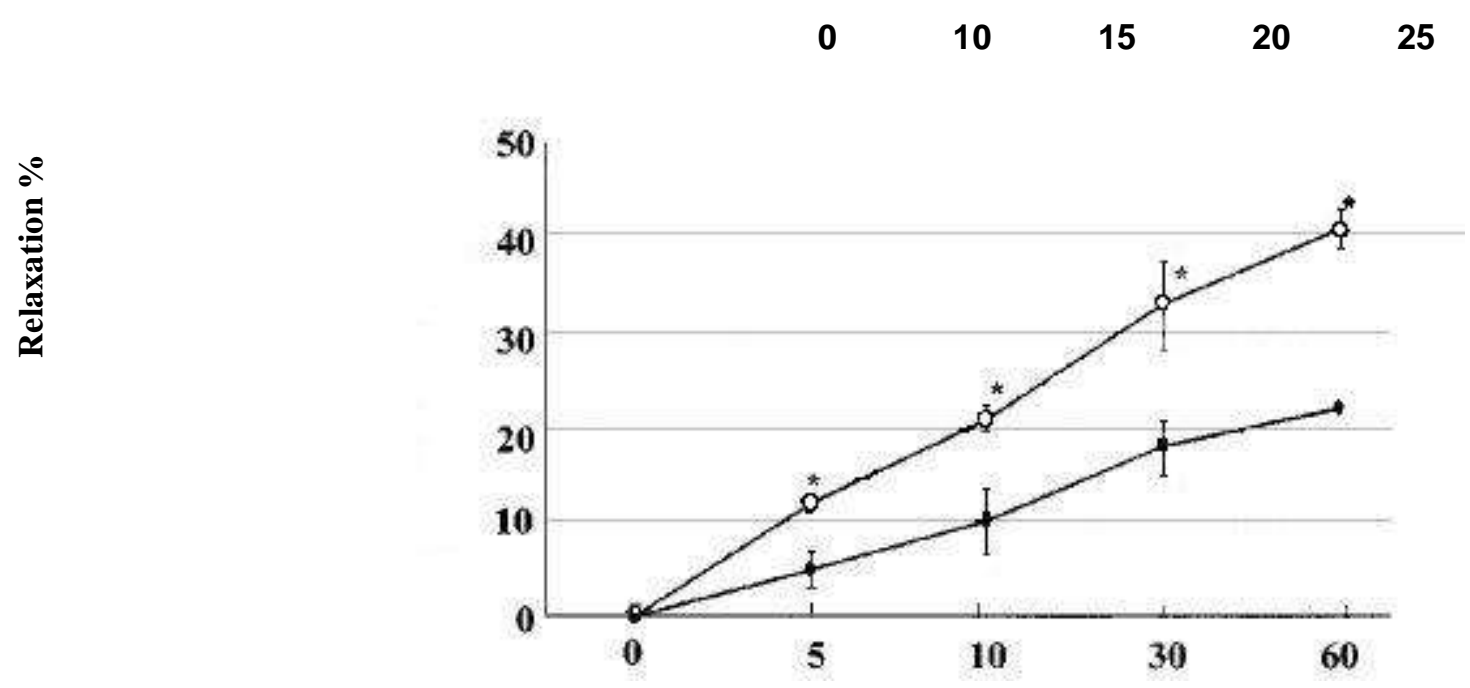

Concentration of Cordia myxa extract \%

Figure 2: Potentiation of relaxation in epithelium denuded sheep trachea. The tracheal rings were relaxed in an exposure-dose dependent manner. The results are measured as peak amplitudes and expressed as percentages of the acetylcholine-induced contraction in the same rings. Values represent the means of 6 separated $\pm \mathrm{SE}$ experiments performed. w/epi represents the epithelium present and w/o epi represents the epithelium denuded sheep trachea . ${ }^{*} \mathrm{P}<0.01$ vs. w/epi and w/o epi of treatment.

\section{Effect of $\mathrm{Ca}^{2+}$-free and verapamil containing medium on Cordia myxa extract -induced relaxation}

As it has been reported that nitric oxide (NO) is a second messenger molecule with diverse functions, such as, vasodilatation, neurotransmission and platelet aggregation. It is formed in an oxygen-dependent reaction during which Larginine is converted into Lcitrulline by the enzyme, NO synthase (NOS). The three major categories of the enzyme regulating NO production are the constitutive, calcium-dependent isoforms principally present in epithelial and neuronal cells (eNOS and nNOS, respectively), and the inducible, calcium independent isoform (iNOS) first described in murine macrophage. Thus, to understand which isoform acts as messenger in Cordia myxa extract -induced relaxation, $\mathrm{Ca}^{2+}$-free and $\mathrm{Ca}^{2+}$ - channel blocker, verapamil were introduced in sheep trachea.

The magnitude of the potentiation of Cordia myxa extract -induced relaxation was significantly $(\mathrm{P}<0.01)$ decreased in the $\mathrm{Ca}^{2+}$ - free medium, and completely diminished in verapamil treated trachea (Figure 5). 


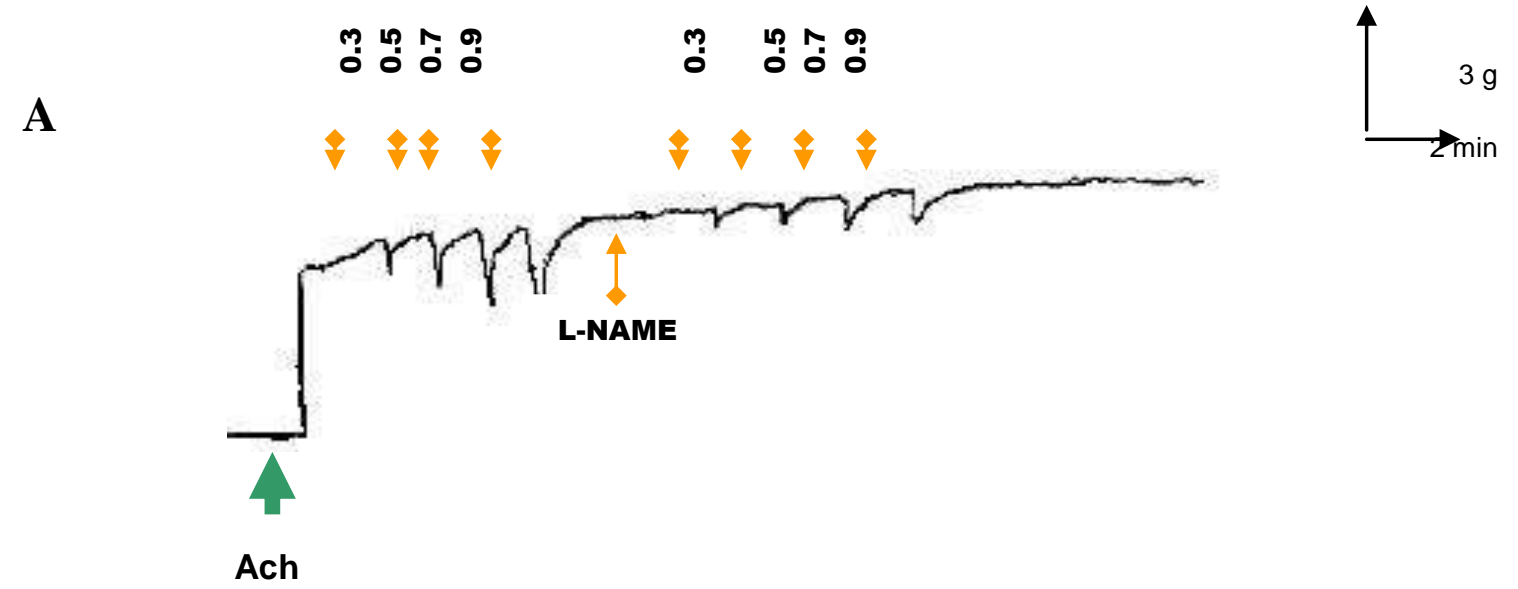

B

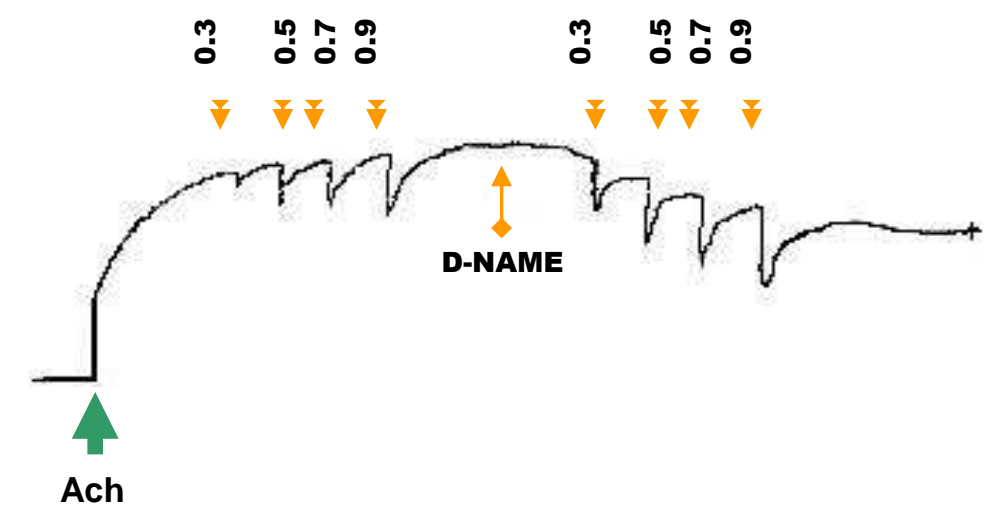

C

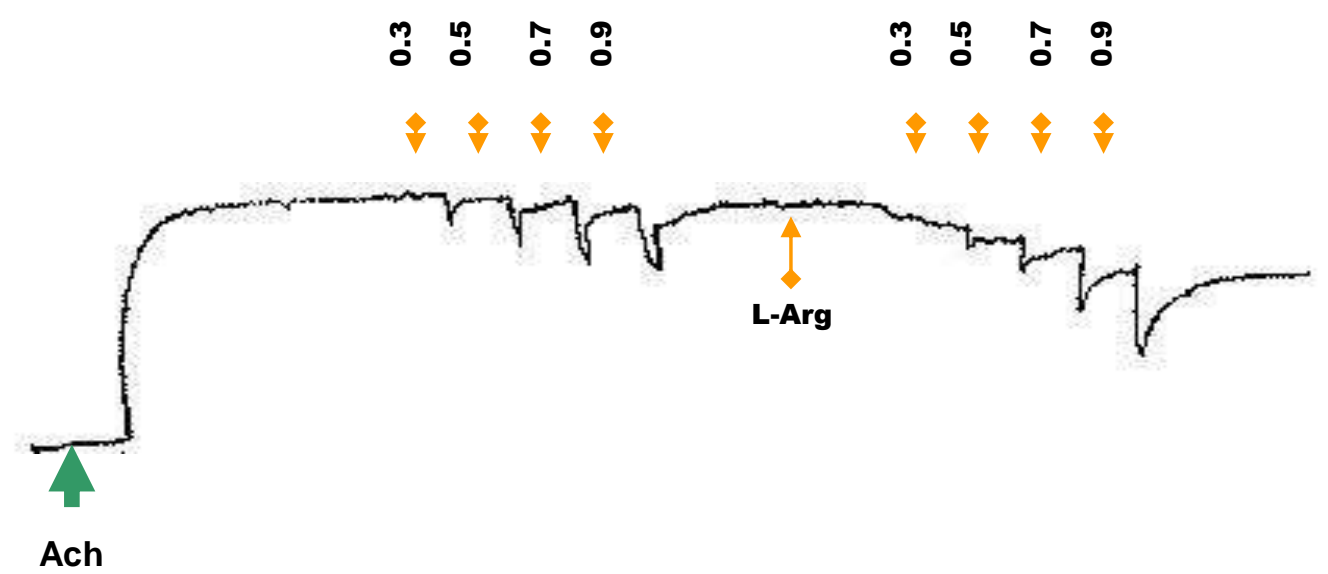

Figure 3: Effects of L-NAME (A. $100 \mathrm{uM}$ ), D-NAME (B. $100 \mathrm{uM}$ ) and L-Arg $(\mathrm{C}, 10 \mathrm{uM})$ on the Cordia myxa extract -induced relaxation of tracheal sheep. 


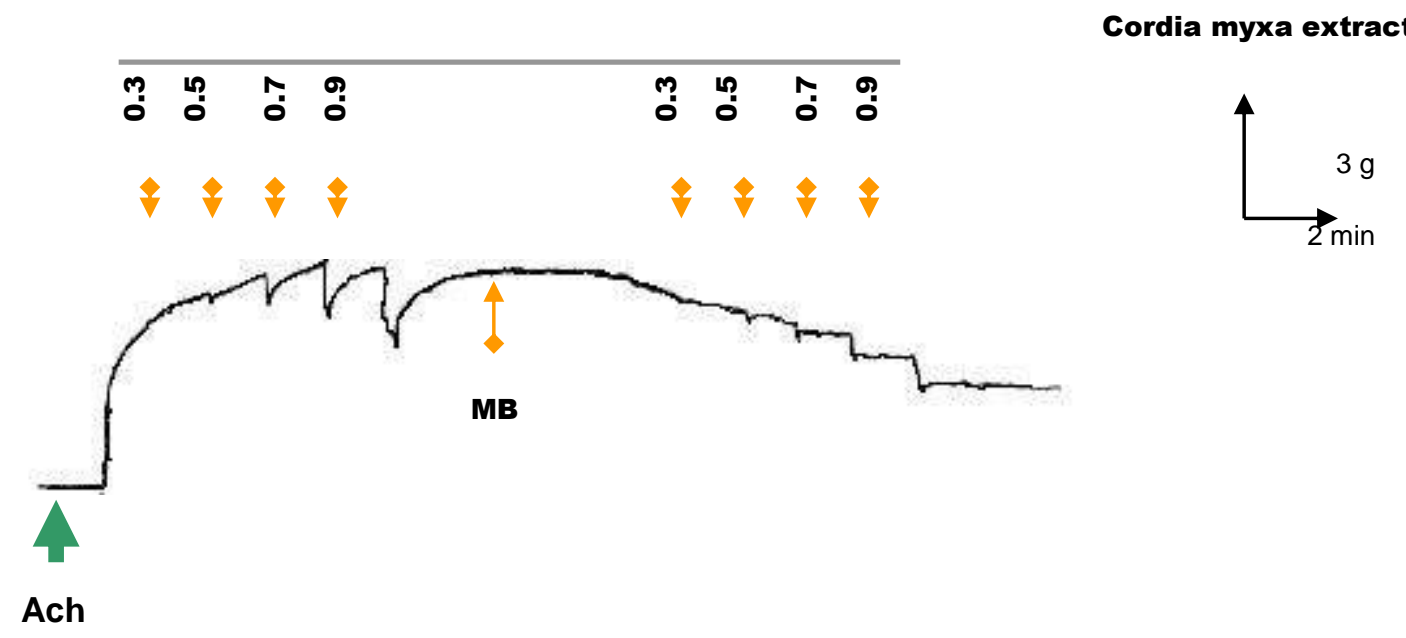

Figure 4: Inhibitory effect of methylene blue (MB, $10 \mathrm{uM})$ on Cordials myxa extract -induced relaxation of tracheal sheep.

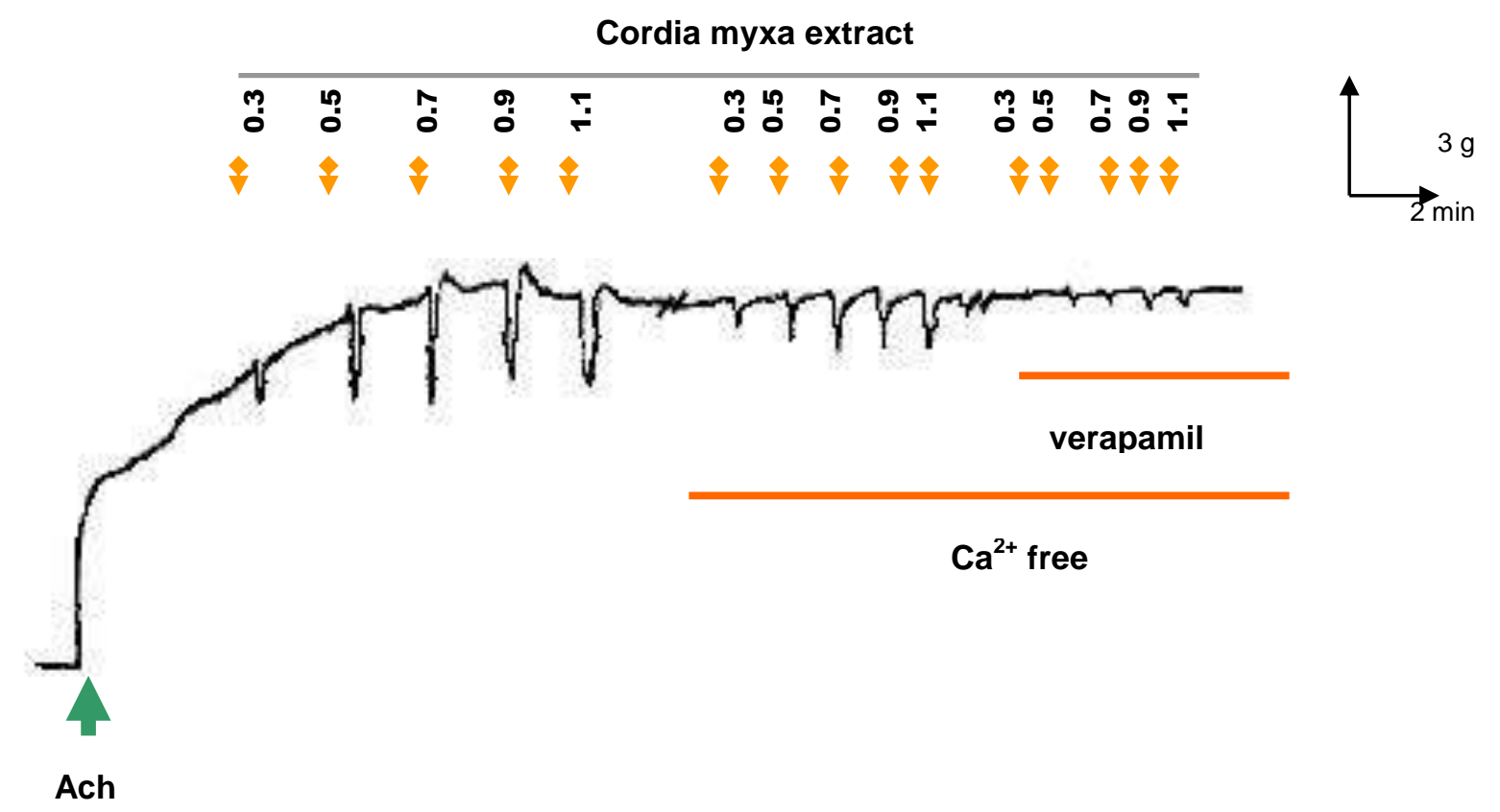

Figure 5: Tracing of the inhibitory action of $\mathrm{Ca}^{2+}$-free and verapamil $\left(0 . \mathrm{I}_{\mathrm{I}} \mathrm{uM}\right)$ on Cordia myxa extract - induced relaxation. 


\section{Discussion}

The impairment of epithelial function is associated with the decreased production of NO and/or a concomitant release of epithelial contracting factors which impair the affect of NO. The epithelial dysfunction observed in asthma appears to be consequences of hyperesponsivness (contraction of tracheal smooth muscle) since a variety of antiasthmatic treatments normalize these responses. However, epithelial dysfunction may amplify the increase in tracheal resistance since the inhibition of NO release causes an increase in hyperesponsiveness (narrowing of tracheal rings). The present study implicated that Cordia myxa extract -induced relaxation is may be due to endotheliumdependent and independent relaxants (Figure 1). We have shown, however, that theophylline - induced tracheal relaxation is absolutely endothelium dependent, but not in Cordia myxa extract-induced relaxation (Figure 1). The magnitude of the potentiation of relaxation is rather greater in epithelium-denuded than endothelium-intact sheep trachea (Figure 1,2). Although, this did not unequivocally indicate that other factors in addition to epithelium derived relaxing factor (EpDRF) exist, it at least showed that smooth muscle is related to Cordia myxa extract-induced relaxation. salbutamol produces relaxation in tracheal smooth muscle via an epithelium-dependent mechanism (12 and 1).

Nitric oxide (NO) is an important factor involved in this response and is released from the endothelium following the binding of dopamine to adrenergic receptors (13 and 7). NO diffuses to the adjacent smooth muscle cells where it stimulates soluble guanylyl cyclase activity leading to increased cGMP levels (14). To demonstrate the characteristic of Cordia myxa extract-induced relaxation, the administration of NOS inhibitor, L-NAME, its derivative, DNAME, and NO donor, L-arginine, significantly induced the magnitude of potentiation of relaxation on L-NAME treatment, but it was not decreased with D-NAME treatment, in contract with the L-NAME treatment, relaxation was slightly increased by D-NAME treatment (Figure 3). In addition, treatment with L-arginine significantly augmented the magnitude of the potentiation of relaxation. This result is consistent with previous reports (15).

The present study shows the significant inhibitory effect of methylene blue upon Cordia myxa extract-induced relaxation (Figure 4). These findings imply that Cordia myxa extract-induced relaxation is due to an interaction of the NOS and cGMP pathways. These results coincide with the suggestion of 3;10 and 16 that Cordia myxa extract treatment of tracheal smooth muscle (relaxation) produces a labile induced relaxing factor (IRF) which, similar to epithelium-derived relaxing factor (EpDRF), elevates cGMP levels and induces relaxation. It has been reported that smooth muscle contains a depletable store of NO which is extract-activated and restored by NO donors (15 and 17). NO is 
formed in an oxygen-dependent reaction during which L-arginine is converted into L-citrulline by the enzyme, NO synthase (NOS). The three major categories of the enzyme regulating NO production are the constitutive, calcium-dependent isoforms principally present in endothelial and neuronal cells (eNOS and nNOS, respectively), and the inducible, calcium independent isoform (iNOS) first described in murine macrophage $(18 ; 5)$.

Thus, to determine which isoform acts as messenger in Cordia myxa extract-induced relaxation, $\mathrm{Ca}^{2+}$-free and $\mathrm{Ca}^{2+}$ - channel blocker, verapamil were introduced in rat aortas. The magnitude of potentiation of Cordia myxa extract induced relaxation was significantly decreased in $\mathrm{Ca}^{2+}$-free medium, and completely diminished in verapamil treated trachea (Figure 5). This result means that the majority of the Cordia myxa extract -induced relaxation might be due to $\mathrm{Ca}^{2+}$ - dependent relaxing factor. It suggests the plausibility of a relation involving $\mathrm{Ca}^{2+}$-dependent NOS such as eNOS and nNOS, except inducible NOS (iNOS). Finally, Cordia myxa extract induced relaxation is due to the expression and activation of $\mathrm{Ca}^{2+}$-dependent NOS isoforms such as eNOS and nNOS but not iNOS (8 and 19)

\section{References}

1. Elias JA, Zhu Z, Chupp G, Homer RJ (1999). Airway remodeling in asthma. $J$ Clin Invest 104: 1001-1006.

2. Bousquet J, Jeffery PK, Busse WW, Johnson M, Vignola AM (2000). Asthma. From bronchoconstriction to airways inflammation and remodeling. Am. J. Respir. Crit. Care Med. 161: 1720-1745.

3. Abou-Shaaban R, Al-Angari A, El-Tahir K, Al-Khamis K and Mirghani O. (1989). Comparative hypertensive and respiratory stimulation effects of ripe and unripe fruit mucilage of Cordia myxa and Cordia oblique in guinea pig and rabbits. Phytotherapy Research, 3: 4. $126-130$.

4. Barnes PJ, Liew FY(1995). Nitric oxide and asthmatic inflammation. Immunol Today 16: 128-130.

5. Blease K, Kunkel SL, Hogaboam CM (2000). Acute inhibition of nitric oxide exacerbates airway hyperresponsiveness, eosinophilia and C-C chemokine generation in a murine model of fungal asthma. Inflamm Res 49: 297-304. 
6. Occhiuto F, Circosta C, and DE Pasquale C. (1989). Study on some medicinal plants of Senegal: Effects on isolated guinea pig ileum. J Ethnopharmacology 26 205-210.

7. Meurs H, Maarsingh H, Zaagsma J (2003). Arginase and asthma: novel insights into nitric oxide homeostasis and airway hyperresponsiveness. Trends Pharmacol Sci 24: 450-455.

8. De Sanctis GT, MacLean JA, Hamada K, Mehta S, Scott JA, Jiao A, Yandava CN, Kobzik L, Wolyniec WW, Fabian AJ, Venugopal CS, Grasemann H, Huang PL, Drazen JM (1999). Contribution of nitric oxide synthases 1, 2, and 3 to airway hyperresponsiveness and inflammation in a murine model of asthma. $J$ Exp Med 189: 1621-1630.

9. De Sousa Mucida D, de Castro Keller A, Fernvik EC, Russo M (2003). Unconventional strategies for the suppression of allergic asthma. Curr Drug Targets Inflamm Allergy 2: 187-195.

10. Barnes PJ (1995)Nitric oxide and airway disease. Ann Med 27: 389-393.

11. Staff of the department of pharmacology university of Edinburgh (1980). The guinea pig tracheal chain. In:Pharmacological experiments on isolated preparations.(2 ${ }^{\text {nd. }}$ Ed.) Churchill Livingstone, London. 100-103.

12. Ricciardolo FL (2003). Multiple roles of nitric oxide in the airways. Thorax 58: $175-182$.

13. Van der Vliet A, Eiserich JP, Cross CE (2000). Nitric oxide: a proinflammatory mediator in lung disease? Respir Res 1: 67-72.

14. Yates DH (2001). Role of exhaled nitric oxide in asthma. Immunol Cell Biol79:178-190.

15. Wu G, Morris Jr SM (1998). Arginine metabolism: nitric oxide and beyond. Biochem J 336 (Pt 1): 1-17.

16. Guo FH, Comhair SA, Zheng S, Dweik RA, Eissa NT, Thomassen MJ, Calhoun W, Erzurum SC (2000). Molecular mechanisms of increased nitric oxide (NO) in asthma: evidence for transcriptional and post-translational regulation of NO synthesis. J Immunol 164: 5970-5980. 
17. Xiong Y, Karupiah G, Hogan SP, Foster PS, Ramsay AJ (1999). Inhibition of allergic airway inflammation in mice lacking nitric oxide synthase 2.J. Immunol 162: 445-452.

18. Xia Y, Roman LJ, Masters BS, Zweier JL(1998). Inducible nitric-oxide synthase generates superoxide from the reductase domain. J Biol Chem 273: 22635-22639.

19. Trifilieff A, Fujitani Y, Mentz F, Dugas B, Fuentes M, Bertrand C(2000). Inducible nitric oxide synthase inhibitors suppress airway inflammation in mice through down-regulation of chemokine expression. J Immunol 165: 1526-1533. 